\title{
Kelimpahan Vegetasi dan Simpanan Biji Gulma pada Pertanaman Jagung Berbeda Sejarah Pola Tanam di Lahan Kering
}

\author{
Weed Abundance and Seed Bank on Maize Field from \\ Different History of Cropping Pattern in Dry Land
}

\author{
Andreas Kefi ${ }^{1}$, Dwi Guntoro ${ }^{2 *}$, dan Edi Santosa ${ }^{2}$ \\ ${ }^{1}$ Program Studi Agronomi dan Hortikultura, Sekolah Pascasarjana, Institut Pertanian Bogor \\ ${ }^{2}$ Departemen Agronomi dan Hortikultura, Fakultas Pertanian, Institut Pertanian Bogor \\ (Bogor Agricultural University), Jl. Meranti, Kampus IPB Darmaga, Bogor 16680, Indonesia
}

Diterima 24 November 2019/Disetujui 20 Januari 2020

\begin{abstract}
Weed management is an important aspect in the dry land; however, weed resides in dry land like East Nusa Tenggara is rarely reported. The study aimed to evaluate weed species and its seed bank on maize fields from the different history of cropping patterns in order to develop effective weed control. The research was conducted in April-June 2019 at farmer fields at Kupang District, East Nusa Tenggara, Indonesia. Weeds were evaluated from four maize fields experienced a different history of cropping pattern (L1, L2, L3, and L4), and its seed bank from the depth of 0-10, 11-20, 21-30, and 31-40 cm were evaluated using seedling emergence method. The evaluation revealed 13 species at which 4 species exclusively were found in vegetation analysis, 2 species in the seed bank and 7 species in both vegetation and seed bank analysis. Dominant weed at podzolic L2 and L3 that experienced fallow for two months was Chloris barbata, while without fallow of podzolic L1 and grumusol L4 were Digitaria adscendens and Mazus japonicus, respectively. Cropping history and soil depths affected weed density, but depths of 0-20 cm had the highest density irrespective preceding the cropping pattern. Research implies both vegetation and seed bank analysis should be addressed and integrated in weed management.
\end{abstract}

Keywords: dry land, fallow, weed management, East Nusa Tenggara, vegetation analysis

\section{ABSTRAK}

Pengelolaan gulma merupakan aspek penting pada pertanaman lahan kering, namun demikian informasi vegetasi gulma dari daerah kering seperti Nusa Tenggara Timur (NTT) masih jarang di laporkan. Penelitian bertujuan mengidentifikasi jenis gulma dan simpanan biji pada pertanaman jagung dengan sejarah pola tanam berbeda dalam rangka mengembangkan metode pengendalian yang efektif. Penelitian dilakukan pada April-Juni 2019 di lahan petani Kabupaten Kupang, NTT, Indonesia. Analisis vegetasi gulma dilakukan pada empat lahan berbeda sejarah pola tanam dan jenis tanahnya (L1, L2, L3, dan L4), dan simpanan biji gulma diamati dari kedalaman 0-10, 11-20, 21-30, dan 31-40 cm menggunakan metode perkecambahan. Hasil penelitian memperoleh 13 jenis gulma; dari jumlah tersebut ada 4 jenis hanya ditemukan pada analisis vegetasi, 2 jenis hanya ditemukan pada simpanan biji, dan 7 jenis ditemukan pada analisis vegetasi dan simpanan biji. Tanah podzolik L2 dan L3 yang bera dua bulan didominasi Chloris barbata, sedangkan podzolik L1 dan grumusol L4 berturutturut adalah Digitaria adscendens dan Mazus japonicus. Sejarah pola tanam dan kedalaman simpanan biji memengaruhi kepadatan gulma; kedalaman 0-20 cm memiliki kepadatan tertinggi pada semua sejarah pola tanam. Penelitian berimplikasi vegetasi dan simpanan biji perlu dipertimbangkan dalam kegiatan pengelolaan gulma.

Kata kunci: Analisis vegetasi, bera, lahan kering, Nusa Tenggara Timur, pengelolaan gulma

\section{PENDAHULUAN}

Jagung merupakan salah satu pangan pokok penduduk Nusa Tenggara Timur (NTT) dengan tingkat konsumsi tahunan per kapita $38.28 \mathrm{~kg}$ (BPS 2018). Namun

\footnotetext{
* Penulis untuk korespondensi. e-mail: edisang@gmail.com
}

berdasarkan data BPS (2018), mengalami kekurangan produksi jagung 191.45 ton tahun 2018 NTT dan terjadi penurunan produktivitas sebesar $2.63 \%$ dibandingkan tahun 2017. Oleh karena itu, peningkatan produksi jagung di NTT perlu dilakukan.

Peningkatan produksi jagung di NTT tidak mudah dilakukan karena keterbatasan air dan tenaga kerja (Matheus et al., 2017; Rohi et al., 2018). Menurut Matheus et al. 
(2017) wilayah NTT memiliki tipe iklim kering D-E dengan jumlah bulan basah 3-4 bulan dan bulan kering 4-6 bulan dengan distribusi dan intensitas curah hujan pada bulan basah tidak merata. Para petani menyiasati keterbatasan tersebut melalui penerapan pola tanam diikuti alokasi tenaga kerja secara tepat. Tetapi para petani mengeluhkan kurang efektifnya pengendalian gulma.

Secara umum, gulma merugikan produksi tanaman utama karena kompetisi (Guntoro et al., 2009). Kehadiran gulma di areal pertanaman jagung menurunkan hasil hingga 5-26\% (Fickett et al., 2013). Oleh karena itu, keberadaan gulma perlu dikendalikan secara efektif. Efektivitas pengendalian gulma dipengaruhi oleh jenis (Chauhan et al. (2017), simpanan biji, dan kepadatan (Koocheki et al., 2009; Anderson, 2010), intensitas pengendalian dan manajemen gulma (Santosa et al., 2006; Tantra dan Santosa, 2016; Zarwazi et al., 2016). Namun penyebab kurang efektifnya kegiatan pengendalian gulma pada pertanaman jagung di NTT masih belum diketahui karena status gulmanya masih jarang dilaporkan.

Menurut Chauhan et al. (2017) agar pengendalian gulma dapat dilakukan secara efektif perlu diketahui jenis gulma target. Salah satu cara untuk mengetahui jenis gulma adalah dengan melakukan analisis vegetasi dan mengetahui sejarah tanaman sebelumnya (Kuht et al., 2016). Penelitian bertujuan mengidentifikasi vegetasi dan simpanan biji gulma di pertanaman jagung yang memiliki sejarah pola tanam berbeda dalam rangka merumuskan strategi pengendalian.

\section{BAHAN DAN METODE}

Penelitian dilaksanakan pada April-Juni 2019 di lahan tadah hujan milik petani di Kelurahan Tua'tuka, Kecamatan Kupang Timur, Kabupaten Kupang, Nusa Tenggara Timur (NTT), Indonesia (-10.1552285 S; 123.838727 E; 65 m dpl; Gambar 1). Lokasi penelitian memiliki suhu udara harian 22.5-33.9 ${ }^{\circ} \mathrm{C}$ (rata-rata $27.3{ }^{\circ} \mathrm{C}$ ), kelembaban udara 46.6$92.7 \%$ (rata-rata $75.9 \%$ ) dan curah hujan saat musim hujan 12-92 $\mathrm{mm}$ (rata-rata $46.7 \mathrm{~mm}$ ).

Penelitian dilakukan di empat lahan milik petani

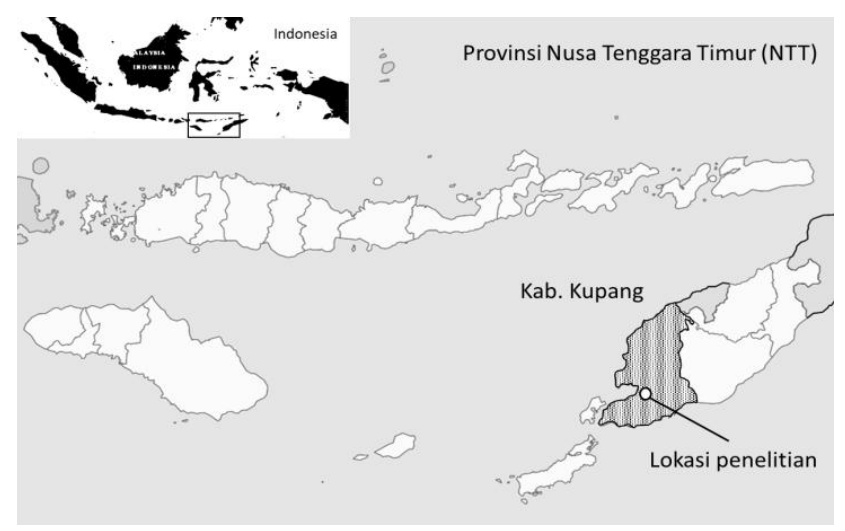

Gambar 1. Lokasi penelitian di Kelurahan Tua'tuka, Kecamatan Kupang Timur, Kabupaten Kupang. Gambar dimodifikasi dari https://id.wikipedia.org. berbeda yang dipilih berdasarkan sejarah pola tanam, dan dua lahan diantaranya memiliki jenis tanah berbeda (Gambar 2). Luas lahan bervariasi antara $0.20-0.35$ ha. Sejarah lahan dan pola tanam diperoleh dari hasil wawancara dengan petani pemilik. Pola tanam pada Lahan 1 (L1), Lahan 2 (L2) dan Lahan 4 (L4), pada November 2018-April 2019 adalah lahan tumpangsari jagung, kacang hijau, dan ubi kayu. Jagung ditanam dengan jarak $2 \mathrm{~m}$ x $1 \mathrm{~m}$, dan kacang hijau dan ubi kayu ditanam di antara barisan jagung. Lahan 3 (L3) ditanami padi gogo dan jagung secara tumpangsari dengan jarak tanam padi $20 \mathrm{~cm}$ x $15 \mathrm{~cm}$ diantara barisan jagung. Pada periode sebelumnya yakni September-Oktober 2018, L2 dan L3 dilakukan bera, sedangkan pada L1 dan L4 masingmasing ditanami jagung dan cabai. Jarak tanam jagung monokultur adalah $40 \mathrm{~cm}$ x $70 \mathrm{~cm}$, dan cabai monokultur $50 \mathrm{~cm}$ x $50 \mathrm{~cm}$ x $70 \mathrm{~cm}$. Tanah pada L1, L2, dan L3 adalah podsolik merah kuning (PMK) dengan tekstur lempung berpasir, sedangkan tanah pada L4 adalah grumusol kelabu hitam dengan tekstur lempung berat. Jagung, kacang hijau, dan ubi kayu yang ditanam merupakan varietas lokal.

Pada lokasi penelitian, jagung ditanam serentak. Sejak tanam jagung hingga pengambilan gulma (6 minggu setelah tanam) tidak dilakukan pengendalian gulma. Vegetasi gulma diambil secara acak 3 ulangan menggunakan kuadran $1 \mathrm{~m} \mathrm{x}$ $1 \mathrm{~m}$ (Gambar 3). Gulma dipotong menggunakan sabit, lalu dihitung per spesies (Gambar 3C) dan selanjutnya dioven pada suhu $75^{\circ} \mathrm{C}$ selama 3 hari. Identifikasi spesies mengacu pada Tjitrosoepomo (2008). Nilai jumlah dominasi (NJD) dihitung menurut Heddy (2012) yakni: $=\frac{K N+B K N+F N}{3} \times 100 \%$; dimana $\mathrm{KN}=$ kerapatan nisbi, $\mathrm{BKN}=$ bobot kering nisbi dan $\mathrm{FN}=$ frekuensi nisbi.

Jumlah biji gulma dihitung dari individu dewasa yang berumur sekitar 3 bulan. Gulma diperoleh dari sekitar lokasi penelitian. Jumlah biji merupakan nilai rata-rata dari tiga individu.

Analisis jumlah simpanan biji menggunakan metode perkecambahan (seedling emergence method) (Hussain et al., 2017). Tanah digali ukuran $25 \mathrm{~cm} \times 35 \mathrm{~cm} \times 40$ cm (PxLxT) dengan 4 ulangan. Sebelum digali, gulma dipermukaan dicabut dan dibersihkan. Tanah dipisahkan berdasarkan 4 kedalaman: 0-10, 11-20, 21-30, dan 31-40 $\mathrm{cm}$. Tanah dihamparkan pada wadah dengan ketebalan 3-5 $\mathrm{cm}$ (Gambar 3D), dan areal persemaian dilindungi plastik untuk menghindari investasi gulma dari luar. Persemaian disiram setiap hari. Pengamatan dilakukan mingguan hingga 4 minggu setelah semai (MSS). Batas 4 minggu mengacu pada viabilitas simpanan biji (Espeland et al., 2010), gulma yang tidak tumbuh atau dorman hingga 4 MSS dianggap tidak viabel. Biji gulma yang tidak viabel tidak dihitung pada penelitian ini.

NJD dihitung menurut Heddy (2012) dan koefisien komunitas (C) dihitung menurut Listyowati (2016) yakni C $=2 \mathrm{~W} /(\mathrm{A}+\mathrm{B}) \times 100 \%$; W: jumlah dari dua kuantitas terendah dari masing-masing spesies, A: jumlah dari seluruh kuantitas pada komunitas pertama; B: jumlah seluruh kuantitas komunitas kedua. 


\begin{tabular}{|c|c|c|c|c|c|c|c|c|c|c|c|c|c|}
\hline Lahan 1 & \multicolumn{4}{|c|}{$\begin{array}{l}\text { Jagung, Ubikayu, Kacang } \\
\text { hijau }\end{array}$} & & g, ub & & \multicolumn{3}{|c|}{$\underline{\text { Jagung }}$} & \multicolumn{2}{|c|}{$\begin{array}{c}\text { Jagung, } \\
\text { Ubikayu, } \\
\text { Kacang hijau }\end{array}$} & $\begin{array}{l}\text { Podzolik } \\
\text { merah kuning }\end{array}$ \\
\hline Lahan 2 & \multicolumn{4}{|c|}{$\begin{array}{l}\text { Jagung, Ubikayu, Kacang } \\
\text { hijau }\end{array}$} & \multicolumn{4}{|c|}{ Jagung, cabai } & \multicolumn{2}{|c|}{$\underline{\text { Bera }}$} & \multicolumn{2}{|c|}{$\begin{array}{c}\text { Jagung, } \\
\text { Ubikayu, } \\
\text { Kacang hijau }\end{array}$} & $\begin{array}{l}\text { Podzolik } \\
\text { merah kuning }\end{array}$ \\
\hline Lahan 3 & \multicolumn{4}{|c|}{ Jagung, padi } & \multicolumn{4}{|c|}{ Jagung, cabai } & \multicolumn{2}{|c|}{$\underline{\text { Bera }}$} & \multicolumn{2}{|c|}{ Jagung, Padi } & $\begin{array}{c}\text { Podzolik } \\
\text { merah kuning }\end{array}$ \\
\hline \multirow[t]{2}{*}{ Lahan 4} & \multicolumn{4}{|c|}{$\begin{array}{l}\text { Jagung, Ubikayu, Kacang } \\
\text { hijau }\end{array}$} & \multicolumn{3}{|c|}{ Jagung } & \multicolumn{3}{|c|}{$\underline{\text { cabai }}$} & \multicolumn{2}{|c|}{$\begin{array}{c}\text { Jagung, } \\
\text { Ubikayu, } \\
\text { Kacang hijau }\end{array}$} & Grumusol \\
\hline & Jan & Feb & Mar & Apr* & Mei & Jun & Jul & Ags & Sep & Okt & Nop & Des & \\
\hline
\end{tabular}

Gambar 2. Perbedaan pola tanam tahunan tiap lahan. Pola telah berlangsung selama 3 tahun berturut-turut. April menunjukkan waktu pengambilan sampel

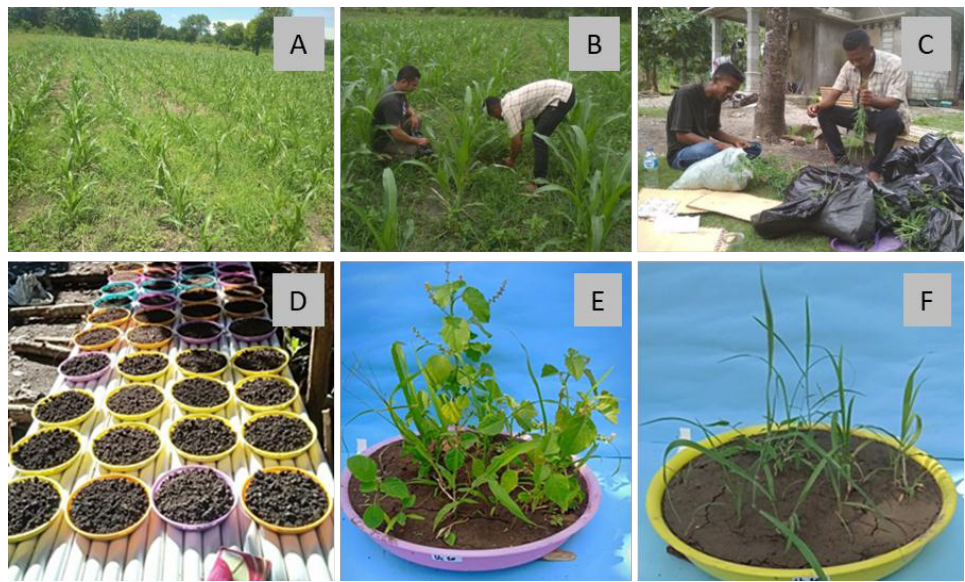

Gambar 3. Analisis vegetasi dan simpanan biji. A. Kondisi lahan pertanaman jagung, B. Pengambilan gulma, C. Pemilahan spesies, D. Persemaian simpanan biji, E. Gulma Mazus japonicus pada 4 minggu setelah semai (MSS), dan F. Gulma Cenchrus echinatus umur 4 MSS

\section{HASIL DAN PEMBAHASAN}

\section{Analisis Vegetasi}

Jumlah gulma yang ditemukan pada analisis vegetasi adalah 11 jenis (Tabel 1). Jumlah tersebut lebih rendah dibandingkan gulma tanaman jagung di lahan kering Kabupten Pohuwatu yakni 14 spesies (Pertiwi dan Arsyad, 2018). Angka tersebut jauh lebih rendah bila dibandingkan dengan jumlah gulma pada pertanaman jagung di agroekologi yang lebih basah seperti 36 spesies di Denpasar, Bali (Suryaningsih et al., 2012), 18 spesies di Kabupaten Lima Puluh Kota (Suveltri et al., 2015), dan 43 spesies di Kab. Muna Barat (Gawaksa et al., 2016). Sedikitnya jumlah spesies yang ditemukan diduga erat kaitannya dengan agroekologi NTT yang merupakan daerah kering, berbeda dengan Denpasar, Lima Puluh Kota, dan Muna Barat (Suryaningsih et al., 2012; Suveltri et al., 2015; Gawaksa et al., 2016).

Tiga dari 11 gulma ditemukan pada semua lahan yakni Chloris barbata, Digitaria adscendens, dan Mazus japonicus; dan secara berturut-turut gulma tersebut dominan pada L2 dan L3, L1, dan L4 (Tabel 1), dan sisanya mengelompok pada lahan tertentu. Lahan L4 memiliki jumlah jenis gulma paling sedikit diantara lahan yang lain. Hal tersebut diduga ada kaitannya dengan jenis tanah L4 yakni grumusol. Menurut Utomo et al. (2016) tanah grumusol (vertisol) memiliki drainase kurang baik, sangat lengket saat hujan, keras dan pecah-pecah saat kemarau. Ada kemungkinan gulma yang umum ditemui di L1, L2, dan L3 tidak mampu beradaptasi pada kondisi drainase kurang baik, atau akarnya mudah putus karena perubahan struktur tanah saat musim kemarau. Namun demikian, hal tersebut membutuhkan penelitian lebih lanjut apakah hipotesis tersebut berlaku untuk Cenchrus echinatus dan Chloris barbata. Sebaliknya, juga perlu dilakukan penelitian terhadap Digitaria adscendens, Digitaria timorensis, Euphorbia geniculate dan Mazus japonicus yang dapat beradaptasi pada tanah grumusol di lahan L4.

Tabel 1 menunjukkan pada L1 hanya ditemukan dua jenis gulma (Brachiaria reptans dan Portulaca oleracea) dan pada L2 hanya satu jenis gulma (Andropogon brevifolius). Dengan asumsi gulma dari L2 dan L3 mewakili kondisi umum pengelolaan lahan di NTT yang melakukan bera 
Tabel 1. Jenis vegetasi gulma, karakteristik dan nisbah jumlah dominansi dari areal pertanaman jagung yang berbeda sejarah pola tanam

\begin{tabular}{|c|c|c|c|c|c|c|c|}
\hline \multirow{2}{*}{ Jenis gulma/Kelompok } & \multirow{2}{*}{ Nama umum } & \multirow{2}{*}{$\mathrm{RP}$} & \multirow{2}{*}{$\mathrm{Y}$} & \multicolumn{4}{|c|}{ NJD lahan $(\%)$} \\
\hline & & & & L1 & $\mathrm{L} 2$ & L3 & L4 \\
\hline Andropogon brevifolius $\mathrm{Sw} . / \mathrm{R}$ & - & VG & ST & 0.0 & 2.9 & 0.0 & 0.0 \\
\hline Brachiaria reptans (L.) C.A. Gardner \& C.E. Hubb/R & - & G & ST & 4.3 & 0.0 & 0.0 & 0.0 \\
\hline Cenchrus echinatus L./R & Kakasangan & G & ST & 9.7 & 27.3 & 19.7 & 0.0 \\
\hline Chloris barbata Sw./R & - & G & ST & 30.2 & 38.8 & 38.7 & 0.0 \\
\hline Digitaria adscendens (Kunth) Henr./R & Genjoran & G & ST & 38.8 & 3.7 & 17.2 & 12.4 \\
\hline Digitaria timorensis (Kunth) Balansa/R & - & G & ST & 0.0 & 6.3 & 1.0 & 10.9 \\
\hline Eleusin indica $(\mathrm{L}$.$) Gaertn/R$ & Belulangan & G & ST & 0.0 & 2.8 & 0.4 & 0.0 \\
\hline Euphorbia geniculate Ortega/DL & Spurge weed & G & ST & 5.0 & 6.5 & 1.1 & 7.7 \\
\hline Euphorbia hirta $\mathrm{L} . / \mathrm{DL}$ & Patikan kebo & G & ST & 0.0 & 1.9 & 3.5 & 0.0 \\
\hline Mazus japonicus (Thunb.) Kuntze/DL & Mata keuyep & VG & $\mathrm{T}$ & 9.0 & 9.8 & 18.4 & 69 \\
\hline Portulaca oleracea $\mathrm{L} . / \mathrm{DL}$ & Krokot & $\mathrm{G}$ & ST & 3.0 & 0.0 & 0.0 & 0.0 \\
\hline
\end{tabular}

Keterangan: $\mathrm{R}=$ rumput; $\mathrm{DL}=$ daun lebar; $\mathrm{RP}=$ cara perbanyakan; $\mathrm{V}=$ vegetatif; $\mathrm{G}=$ generatif; $\mathrm{Y}=$ Siklus hidup; $\mathrm{ST}=$ setahun; $\mathrm{T}=$ tahunan; NJD = nisbah jumlah dominansi

pada Agustus-Oktober, perubahan gulma dominan pada L4 dan L1 mengindikasikan adanya pergeseran jenis. Pada L2 dan L3 gulma dominan adalah Chloris barbata, bergeser menjadi Digitaria adscendens pada L1 dan menjadi Mazus japonicas pada L4. Penulis berspekulasi bahwa pergeseran jenis gulma pada L4 diduga karena kombinasi faktor sejarah pola tanam dan jenis tanah, sedangkan pergeseran pada L1 disebabkan oleh perbedaan sejarah pola tanam. Berdasarkan sejarah pola tanam, lahan L2 dan L3 mengalami bera sedangkan L1 ditanami jagung (Gambar 2); penanaman jagung tersebut diduga mampu menggeser dominansi gulma Chloris barbata menjadi Digitaria adscendens.

\section{Simpanan Biji Gulma}

Simpanan biji gulma yang tumbuh ada 9 jenis (Tabel 2). Jumlah total simpanan biji gulma terbanyak adalah Chloris barbata diikuti Mazus japonicus dan Dactyloctenium aegyptium, sedangkan gulma paling sedikit adalah Brachiaria reptans.

Delapan dari 9 jenis gulma mulai berkecambah pada 1 MSS kecuali Borreria alata (Tabel 2). Enam dari 9 jenis gulma berkecambah hingga 4 MSS kecuali pada Brachiaria reptans, Digitaria timorensis dan Eleusine indica yang pada $4 \mathrm{MSS}$ sudah tidak ada lagi yang berkecambah. Dilihat dari laju perkecambahan, terdapat 3 pola yakni beberapa gulma memiliki perkecambahan tertinggi pada $1 \mathrm{MSS}$ dan menurun pada minggu berikutnya seperti pada gulma Brachiaria reptans, Cenchrus echinatus, dan Eleusine indica. Pola berikutnya yakni jenis yang perkecambahan pada 1 MSS relatif rendah kemudian meningkat pada 2 MSS dan bertahan atau menurun kembali pada 3 atau 4 MSS seperti pada jenis Digitaria adscendens, Digitaria timorensis dan Mazus japonicus. Pola ketiga adalah yang perkecambahannya relatif stabil tinggi sejak 1-3 MSS seperti pada Chloris barbata. Penyebab perbedaan pola perkecambahan tersebut belum dapat ditentukan karena keterbatasan ulangan pada penelitian ini. Perlu penelitian apakah perbedaan pola perkecambahan tersebut ditentukan oleh jenis gulma, jenis tanah atau interaksi jenis gulma dan tanah; termasuk perlu diteliti jumlah biji yang masih dorman dalam tanah.

Tabel 2 menunjukkan bahwa gulma memiliki perbedaan jumlah simpanan biji menurut kedalaman tanah. Semua lapisan tanah $(0-40 \mathrm{~cm})$ memiliki investasi simpanan biji yang viabel, kecuali jenis Borreria alata yang tidak ditemukan pada kedalaman 31-40 cm. Secara umum, jumlah simpanan biji terbanyak ditemukan pada kedalaman 0-20 cm, kecuali jenis Chloris barbata yang masih banyak ditemukan pada pada kedalaman 31-40 cm sebanyak 198 individu yang sama banyaknya dengan kedalaman 11-20 $\mathrm{cm}$. Namun demikian, ada kecenderungan penurunan jumlah simpanan biji seiring dengan peningkatan kedalaman tanah. Menurut Shiferaw et al. (2018) kondisi tanah menjadi penentu penyebaran simpanan biji gulma dalam tanah.

Berdasarkan sejarah pola tanam, simpanan biji pada L1 memiliki 11 jenis, L2 memiliki 9 jenis, L3 memiliki 8 jenis dan L4 memiliki 7 jenis gulma (data tidak ditampilkan). Setiap lahan memiliki satu jenis gulma yang berbeda yakni pada L1, L2 dan L3 berturut-turut adalah Portulaca oleracea, Andropogon brevifolius, dan Euphorbia hirta. Masih perlu kajian lebih lanjut, apakah jenis-jenis tersebut dapat dijadikan sebagai penciri simpanan biji untuk lahan dengan sejarah pola tanam yang berbeda di NTT.

Terdapat perbedaan kerapatan simpanan biji antar lahan dengan sejarah pola tanam berbeda, dan antar waktu (data tidak ditampilkan). Lahan bekas areal tanam jagung (L1) memiliki tingkat kerapatan total gulma tertinggi pada 2-3 MSS. Kerapatan tertinggi pada Lahan L4 (bekas tanaman cabai) dicapai pada 2 MSS. Pada 2 MSS, kerapatan gulma pada L4 lebih tinggi dibandingkan dengan pada L2 dan L3 yang keduanya dilakukan bera. L1, L2, dan L3 
Tabel 2. Jumlah simpanan biji gulma pada berbagai kedalaman tanah

\begin{tabular}{|c|c|c|c|c|c|c|}
\hline \multirow{2}{*}{$\begin{array}{l}\text { Spesies gulma } \\
\text { [nama umum] }\end{array}$} & \multirow{2}{*}{$\mathrm{KT}(\mathrm{cm})$} & \multicolumn{4}{|c|}{ Jumlah kecambah baru dari gulma } & \multirow{2}{*}{ Total individu } \\
\hline & & $1 \mathrm{MSS}$ & $2 \mathrm{MSS}$ & $3 \mathrm{MSS}$ & $4 \mathrm{MSS}$ & \\
\hline \multirow{5}{*}{$\begin{array}{l}\text { Borreria alata (Aubl.) DC } \\
\text { [Goletrak] }\end{array}$} & $0-10$ & 0 & 8 & 0 & 0 & 8 \\
\hline & $11-20$ & 0 & 15 & 0 & 15 & 30 \\
\hline & $21-30$ & 0 & 4 & 32 & 34 & 70 \\
\hline & $31-40$ & 0 & 0 & 0 & 0 & 0 \\
\hline & Jumlah & 0 & 27 & 32 & 49 & 108 \\
\hline \multirow{5}{*}{$\begin{array}{l}\text { Brachiaria reptans (L.) C.A. } \\
\text { Gardner \& C.E. Hubb }\end{array}$} & $0-10$ & 0 & 8 & 0 & 0 & 8 \\
\hline & $11-20$ & 12 & 0 & 0 & 0 & 12 \\
\hline & $21-30$ & 0 & 1 & 0 & 0 & 1 \\
\hline & $31-40$ & 0 & 0 & 7 & 0 & 7 \\
\hline & Jumlah & 12 & 9 & 7 & 0 & 28 \\
\hline \multirow[t]{5}{*}{ Cenchrus echinatus L. } & $0-10$ & 47 & 14 & 4 & 0 & 65 \\
\hline & $11-20$ & 15 & 1 & 4 & 0 & 20 \\
\hline & $21-30$ & 0 & 14 & 2 & 13 & 29 \\
\hline & $31-40$ & 0 & 2 & 8 & 0 & 10 \\
\hline & Jumlah & 62 & 31 & 18 & 13 & 124 \\
\hline \multirow[t]{5}{*}{ Chloris barbata Sw. } & $0-10$ & 155 & 74 & 115 & 12 & 356 \\
\hline & $11-20$ & 121 & 43 & 29 & 4 & 197 \\
\hline & $21-30$ & 0 & 36 & 35 & 3 & 74 \\
\hline & $31-40$ & 0 & 71 & 106 & 21 & 198 \\
\hline & Jumlah & 276 & 224 & 282 & 40 & 825 \\
\hline \multirow{5}{*}{$\begin{array}{l}\text { Dactyloctenium aegyptium } \\
\text { (L.) Willd }\end{array}$} & $0-10$ & 20 & 20 & 8 & 12 & 60 \\
\hline & $11-20$ & 39 & 20 & 6 & 0 & 65 \\
\hline & $21-30$ & 0 & 8 & 1 & 0 & 9 \\
\hline & $31-40$ & 1 & 15 & 10 & 0 & 26 \\
\hline & Jumlah & 60 & 63 & 25 & 12 & 160 \\
\hline \multirow{5}{*}{$\begin{array}{l}\text { Digitaria adscendens } \\
\text { (Kunth) Henr. }\end{array}$} & $0-10$ & 11 & 14 & 0 & 0 & 25 \\
\hline & $11-20$ & 5 & 10 & 2 & 0 & 17 \\
\hline & $21-30$ & 0 & 9 & 5 & 0 & 14 \\
\hline & $31-40$ & 0 & 8 & 11 & 2 & 21 \\
\hline & Jumlah & 16 & 41 & 18 & 2 & 77 \\
\hline \multirow{5}{*}{$\begin{array}{l}\text { Digitaria timorensis (Kunth) } \\
\text { Balansa }\end{array}$} & $0-10$ & 12 & 10 & 0 & 0 & 22 \\
\hline & $11-20$ & 9 & 7 & 3 & 0 & 19 \\
\hline & $21-30$ & 0 & 9 & 37 & 0 & 46 \\
\hline & $31-40$ & 0 & 0 & 19 & 0 & 19 \\
\hline & Jumlah & 21 & 26 & 59 & 0 & 106 \\
\hline \multirow[t]{5}{*}{ Eleusine indica (L.) Gaertn } & $0-10$ & 12 & 0 & 7 & 0 & 19 \\
\hline & $11-20$ & 4 & 6 & 1 & 0 & 11 \\
\hline & $21-30$ & 0 & 1 & 0 & 0 & 1 \\
\hline & $31-40$ & 0 & 7 & 1 & 0 & 8 \\
\hline & Jumlah & 16 & 14 & 9 & 0 & 39 \\
\hline \multirow{5}{*}{$\begin{array}{l}\text { Mazus japonicus (Thunb.) } \\
\text { Kuntze }\end{array}$} & $0-10$ & 82 & 27 & 10 & 0 & 119 \\
\hline & $11-20$ & 31 & 84 & 51 & 71 & 237 \\
\hline & $21-30$ & 0 & 25 & 6 & 14 & 45 \\
\hline & $31-40$ & 0 & 22 & 28 & 0 & 48 \\
\hline & Jumlah & 113 & 158 & 95 & 85 & 449 \\
\hline
\end{tabular}

Keterangan: $\mathrm{KT}=$ kedalaman tanah; MSS = minggu setelah semai 
masing-masing memiliki nilai kerapatan sebesar 63\%, 46\% dan $41 \%$. Nilai kerapatan total gulma di L4 pada 3 MSS lebih tinggi jika dibandingkan lahan L1, L2, dan L3 yakni sebesar masing-masing 39\%, 44\%, dan 55\%.

\section{Perbandingan Vegetasi dan Implikasi Pengendalian Gulma}

Tingkat kesamaan jenis gulma dari hasil analisis vegetasi dengan simpanan biji adalah sekitar 54\%; terdapat 6 jenis gulma yang berbeda dari analisis vegetasi dan simpanan biji (Tabel 3). Empat jenis gulma ditemukan pada analisis vegetasi namun tidak ditemukan pada simpanan biji yaitu Andropogon brevifolius, Euphorbia geniculate, Euphorbia hirta, dan Portulaca oleracea. Secara teoritis, gulma yang ditemukan pada analisis vegetasi dapat menghasilkan biji yang akan menjadi simpanan biji, artinya bahwa pada keadaan tidak ada gangguan yang berarti, jenis gulma dari analisis vegetasi akan mirip dengan simpanan biji. Tabel 3 menunjukkan bahwa keempat gulma yang tidak memiliki simpanan biji sebenarnya menghasilkan biji yang cukup besar yakni $>1300$ biji m$^{-2}$, kecuali Euphorbia hirta yang menghasilkan 540 biji $\mathrm{m}^{-2}$. Tidak adanya simpanan biji dari keempat gulma tersebut kemungkinan akibat dari kegiatan pengendalian yang sudah cukup efektif atau biji gulma mengalami kematian atau masih dorman sehingga tidak ada yang tumbuh. Menurut Borgy et al. (2015) kemampuan tumbuh simpanan biji dipengaruhi jenis gulma, dan menurut Kuht et al. (2016) adanya predator biji gulma sangat memengaruhi keberadaan simpanan biji.

Di sisi lain, ada dua jenis gulma yakni Borreria alata dan Dactyloctenium aegyptium yang tidak ditemukan pada analisis vegetasi, tetapi memiliki simpanan biji (Tabel 3). Menurut Shiferaw et al. (2018) jenis gulma dari simpanan biji yang tidak ditemukan pada analisis vegetasi sangat mungkin terjadi. Ada kemungkinan simpanan biji tersebut berasal dari luar lokasi penelitian karena ukuran biji Borreria alata dan Dactyloctenium aegyptium relatif kecil dan mampu menyebar lewat angin. Menurut catatan Badan Meteorologi dan Geofisika di Kupang (www.bmkg.go.id), kecepatan angin $>18 \mathrm{~km} \mathrm{jam}^{-1}$ biasa terjadi di wilayah penelitian. Kemungkinan lain adalah investasi dari gulma saat bera karena gulma tersebut hanya ditemukan pada L2 dan L3 yang mengalami bera (Gambar 2).

Tabel 3 menunjukkan bahwa gulma Chloris barbata memiliki produksi biji terbesar. Gulma tersebut juga memiliki jumlah simpanan biji yang lebih besar dibandingkan dengan jenis lain. Akan tetapi, secara relatif, jumlah simpanan biji Chloris barbata hanya sekitar $0.05 \%$ dari total biji yang dihasilkan. Gulma Chloris barbata merupakan gulma setahun (Tabel 1) dan termasuk mudah dikendalikan. Pada lokasi penelitian, petani terbiasa mengendalikan gulma menggunakan herbisida pasca tumbuh berbahan aktif glifosat karena langkanya tenaga kerja.

Data simpanan biji menunjukkan bahwa nilai koefisien komunitas di areal L1 dan L3 pada 1 MSS serta areal L2 dan L3 pada 3 MSS tergolong besar ( $>70 \%$ ), artinya terdapat banyak kesamaan vegetasi (Tabel4). Petani jagung umumnya mengendalian gulma pada 2-3 minggu setelah tanam. Umur tersebut dapat disetarakan dengan 3 MSS semaian gulma pada penelitian ini. Berdasarkan umur tersebut dan tingkat kesamaan komunitas gulma, diperoleh tiga kelompok yakni kelompok L1, kelompok L2+L3, dan kelompok L4. Pembagian kelompok tersebut dapat menjadi pijakan awal untuk kajian lebih lanjut pada aspek pengendalian.

Penelitian ini merupakan temuan awal adanya perbedaan komposisi vegetasi pada pertanaman jagung

Tabel 3. Perbandingan jumlah biji gulma dari vegetasi dan jumlah gulma yang tumbuh dari simpanan biji dari pertanaman jagung di Kabupaten Kupang, Nusa Tenggara Timur

\begin{tabular}{|c|c|c|c|c|c|c|c|}
\hline \multirow{2}{*}{ Spesies Gulma } & \multirow{2}{*}{ Famili } & \multicolumn{2}{|c|}{ Vegetasi $\left(\mathrm{m}^{2}\right)$} & \multicolumn{4}{|c|}{ Simpanan biji $\left(\mathrm{m}^{2}\right)$} \\
\hline & & Individu & Jumlah biji & $0-10$ & $11-20$ & $21-30$ & $31-40$ \\
\hline Andropogon brevifolius $S w . * *$ & Poaceae & 9 & 1,350 & 0 & 0 & 0 & 0 \\
\hline Borreria alata (Aubl.) DC* & Rubiaceae & 0 & 0 & 8 & 30 & 70 & 0 \\
\hline Brachiaria reptans (L.) C.A. Gardner \& C.E. Hubb & Poaceae & 39 & 6,552 & 8 & 12 & 1 & 7 \\
\hline Cenchrus echinatus L. & Poaceae & 520 & 36,400 & 65 & 20 & 29 & 10 \\
\hline Chloris barbata $\mathrm{Sw}$. & Poaceae & 1,297 & $1,712,040$ & 356 & 197 & 74 & 198 \\
\hline Dactyloctenium aegyptium (L.) Willd* & Poaceae & 0 & 0 & 60 & 65 & 9 & 26 \\
\hline Digitaria adscendens (Kunth) Henr. & Poaceae & 850 & 516,800 & 25 & 17 & 14 & 21 \\
\hline Digitaria timorensis (Kunth) Balansa & Poaceae & 41 & 3,075 & 22 & 19 & 46 & 19 \\
\hline Eleusine indica (L.) Gaertn & Poaceae & 7 & 4,228 & 19 & 11 & 1 & 8 \\
\hline Euphorbia geniculate Ort** & Euphorbiaceae & 49 & 2,793 & 0 & 0 & 0 & 0 \\
\hline Euphorbia hirta L.** & Euphorbiaceae & 5 & 540 & 0 & 0 & 0 & 0 \\
\hline Mazus japonicus (Thunb.) Kuntze & Mazaceae & 508 & 109,220 & 119 & 237 & 45 & 50 \\
\hline Portulaca oleracea L.** & Portulacaceae & 9 & 1,620 & 0 & 0 & 0 & 0 \\
\hline
\end{tabular}

Keterangan: * = tidak ditemukan pada analisis vegetasi $; *$ * tidak ditemukan pada simpanan biji 
dengan simpanan biji di lahan kering di NTT. Penerapan pola tanam yang berbeda antar petani termasuk melakukan bera seperti pada penelitian ini, merupakan upaya adaptasi teknologi budidaya terhadap keterbatasan air. Namun demikian, pemilihan teknologi tersebut berimplikasi pada perlunya menerapkan strategi pengendalian gulma yang tepat. Menurut $\mathrm{Gu}$ et al. (2019), lahan bera merupakan sumber utama propagul simpanan biji gulma.

Atas pertimbangan kapasitas produksi biji dan jumlah simpanan biji yang besar (Tabel 3), direkomendasikan untuk melakukan pengendalian gulma secara pra-tumbuhdan pascatumbuh. Pengendalian secara kultur teknis diarahkan pada lahan yang menerapkan bera untuk menekan gulma dengan produksi biji tinggi seperti Cenchrus echinatus, Chloris barbata, Dactyloctenium aegyptium dan Mazus japonicus
(Tabel 3). Pengendalian kultur teknis (http://agritech.tnau. ac.in) dapat dilakukan dengan cara olah tanah lebih dalam dari $30 \mathrm{~cm}$ (deep plowing) setelah pemberlakuan bera untuk mencegah penyebaran biji (block seed transmission) (Gu et al., 2019) maupun dilakukan dengan menanam LCC selama masa bera (Matheus et al., 2018).

Penelitian ini menunjukkan perlunya mempertimbangkan sejarah pola tanam dalam pengendalian gulma di Provinsi NTT. Namun penelitian belum dapat menjelaskan tingkat kompetisi gulma yang ditemukan terhadap tanaman jagung. Diperlukan kajian kompetisi gulma dominan seperti Chloris barbata dengan tanaman jagung untuk membuktikan dugaan petani bahwa penurunan produktivitas jagung pada tahun 2018 disebabkan oleh gulma.

Tabel 4. Nilai koefisien komunitas dari simpanan biji gulma berasal dari lahan dengan pola tanam berbeda pada 1-4 minggu setelah semai

\begin{tabular}{lcccccccc}
\hline \multirow{2}{*}{ Lahan } & \multicolumn{3}{c}{ Nilai koefisien komunitas (\%) } & \multicolumn{4}{c}{ Keseragaman } \\
\cline { 2 - 9 } & 1 MSS & 2 MSS & 3 MSS & 4 MSS & 1 MSS & 2 MSS & 3 MSS & 4 MSS \\
\hline L1 dan L2 & 59.9 & 50.2 & 55.4 & 20.7 & B & B & B & B \\
L1 dan L3 & 72.1 & 46.9 & 66.7 & 28.1 & S & B & B & B \\
L1 dan L4 & 62.4 & 51.7 & 45.3 & 16.8 & B & B & B & B \\
L2 dan L3 & 60.2 & 58.4 & 74.0 & 10.3 & B & B & S & B \\
L2 dan L4 & 54.7 & 45.7 & 64.6 & 4.2 & B & B & B & B \\
L3 dan L4 & 47.8 & 57.1 & 49.1 & 59.7 & B & B & B & B \\
\hline
\end{tabular}

Keterangan: $\mathrm{B}=$ Beragam; S-Seragam; MSS = minggu setelah semai

\section{KESIMPULAN}

Sejarah pola tanam sebelumnya memengaruhi kelimpahan vegetasi dan simpanan biji gulma tanaman jagung. Jumlah simpanan biji gulma terbayak ada pada kedalaman hingga 0-20 cm. Kesamaan jenis gulma antara vegetasi dan simpanan biji dari total 13 species ditemukan adalah 54\% (7 jenis gulma). Dua jenis gulma yaitu Borreria alata dan Dactyloctenium aegyptium hanya ditemukan pada simpanan biji dan empat jenis hanya ditemukan pada vegetasi yaitu Andropogon brevifolius, Euphorbia geniculate, Euphorbia hirta, dan Portulaca oleracea. Penelitian berimplikasi perlunya mempertimbangkan kelimpahan gulma dari vegetasi dan simpanan biji dalam pengelolaan gulma tanaman jagung di NTT.

\section{DAFTAR PUSTAKA}

Anderson, R.L. 2010. A rotation design to reduce weed density in organic farming. Renew. Agric. Food Syst. 25:189-195.

[BPS] Badan Pusat Statistik. 2018. Kabupaten Kupang dalam Angka 2018. http://kupangkab.bps.go.id [15 Nopember 2019].
Borgy, B., X. Reboud, N. Peyrard, R. Sabbadin, S. Gaba. 2015. Dynamics of weeds in the soil seed bank: A hidden markov model to estimate life history traits from standing plant time series. PloS one 10(10): e0139278. Doi:10.1371/journal.pone.0139278.

Chauhan, B.S., A. Matloob, G. Mahajan, F. Aslam, S.K. Florentine, P. Jha. 2017. Emerging challenges and opportunities for education and research in weed science. Chall. Opport. Weed Sci. 8:1-13.

Espeland, E.K., L.B. Perkins, E.A. Leger. 2010. Comparison of seed bank estimation techniques using six weed species in two soil types. Rangeland Ecol. Manage. 63:243-247.

Fickett, N.D., C.M. Boernoom, D.E. Stoltenberg. 2013. Predicted corn yield loss due to weed competition prior to post emergence herbicide application on Wisconsin farms. Weed Tech. 27:54-62.

Gawaksa, H.P., Damhuri, L. Darlian. 2016. Gulma di lahan pertanian jagung (Zea mays L.) di Kecamatan Barangka Kabupaten Muna Barat. J. Ampibi 1:1-9. 
Gu, X., Y. Cen, L. Guo, C. Li, H. Yuan, Z. Xu, G. Jiang. 2019. Responses of weed community, soil nutrients, and microbes to different weed management practices in a fallow field in Northern China. Peer J. 7:7650. Doi:10.7717/peerj.7650

Guntoro, D., M.A. Chozin, E. Santosa, S. Tjitrosemito, A.H. Burhan. 2009. Kompetisi antara ekotipe Echinochloa crus-galli pada beberapa tingkat populasi dengan padi sawah. J. Agron. Indonesia 37:202-208.

Heddy, S. 2012. Metode Analisis Vegetasi dan Komunitas. Rajawali Press, Jakarta, ID.

Hussain, M., S. Ali, M.N. Tahir, G.A. Shah, I. Ahmad, M.A. Sarwar, S. Latif. 2017. A comparative study of soil weed seed bank determination in Pothwar Region by using different methodologies. Pakistan J. Agric. Res. 30:310-315.

Koocheki, A., M. Nassiri, L. Alimoradi, R. Ghorbani. 2009. Effect of cropping systems and crop rotations on weeds. Agron. Sustain. Dev. 29:401-408.

Kuht, J., V. Eremeev, L. Talgre, H. Madsen, M. Toom, E. Mäeorg, A. Luik. 2016. Soil weed seed bank and factors influencing the number of weeds at the end of conversion period to organic production. Agro. Res. 14:1372-1379.

Listyowati,C.2016.Analisis vegetasigulmapadapertanaman ubi kayu di lahan kering di Kecamatan Paliyan Kabupaten Gunungkidul. p. 494-499. In Prosiding Seminar Hasil Penelitian Tanaman Aneka Kacang dan Umbi 2016. Tersedia pada: http://balitkabi. litbang.pertanian.go.id/wp-content/uploads/2017/07/ pros16_60.pdf [15 Nopember 2019].

Matheus, R., M. Basri, M.S. Rompon, N. Neonufa. 2017. Strategi pengelolaan pertanian lahan kering dalam meningkatkan ketahanan pangan di Nusa Tenggrara Timur. Partner 22:529-541.

Matheus, R., D. Kantur, N. Bora. 2018. Innovation of the fallow system with the legume cover crop a season for improved physical properties of soil degradated on dryland farming. Inter. J. Sci. Tech. Res. 7:107111.
Pertiwi, E.D., M. Arsyad. 2018. Keanekaragaman dan dominasi gulma pada pertanaman jagung di lahan kering Kecamatan Marisa Kabupaten Pohuwato. Agrivigor 11:71-76.

Rohi, J.G., R. Winandi, A. Fariyanti. 2018. Analisis faktor yang mempengaruhi produksi usahatani jagung serta efisiensi teknis di Kabupaten Kupang. Forum Agrib. 8:181-198.

Santosa, E., N. Sugiyama, M. Nakata, Y. Mine, O. N. Lee, D. Sopandie. 2006. Effect of weeding frequency on the growth and yield of elephant foot yams in agroforestry systems. Japanese J. Trop. Agric. 50:714.

Santosa, E., S. Zaman, I. D. Puspitasari. 2009. Simpanan biji gulma dalam tanah di perkebunan teh pada berbagai tahun pangkas. J. Agron. Indonesia 37:46-54.

Shiferaw, W., S. Demissew, T. Bekele. 2018. Ecology of soil seed banks: Implications for conservation and restoration of natural vegetation: A review. Internat. J. Biodiv. Conserv. 10:380-393. Doi:10.5897/ IJBC2018.1226

Suryaningsih, M. Joni, A. A. K. Darmadi. 2012. Inventarisasi gulma pada tanaman jagung (Zea mays L.) di lahan sawah Kelurahan Padang Galak, Denpasar Timur, Kodya Denpasar, Provinsi Bali. J. Simbiosis 1:1-8.

Suveltri, B., Z. Syam, Solfiyeni. 2014. Analisa vegetasi gulma pada pertanaman jagung (Zea mays L) pada lahan olah tanah maksimal di Kabupaten Lima Puluh Kota. J. Bio. UA. 3:103-108.

Tantra, A.W., E. Santosa. 2016. Manajemen gulma di kebun kelapa sawit Bangun Bandar: Analisis vegetasi dan seed bank gulma. Bul. Agrohorti 4:138-143.

Tjitrosoepomo, G. 2008. Taksonomi Tumbuhan (Spermatophyta). Gadjah Mada University Press. Yogyakarta. ID.

Utomo, D.H. 2016. Morfologi profil tanah Vertisol di Kecamatan Kraton, Kabupaten Pasuruan. J. Pendidikan Geografi 21:47-57.

Zarwazi, L.M., M.A. Chozin, D. Guntoro. 2016. Potensi gangguan gulma pada tiga sistem budidaya padi sawah. J. Agron. Indonesia 44:147-153. 